ИСТОРИЧЕСКАЯ НАУКА

Karen Petrone

\title{
Eisenstein's Ivan the Terrible and the History of Mentalités
}

Karen Petrone

Professor of History, University of Kentucky (Lexington, USA)
Like Joan Neuberger, I am a cultural historian and my comments on her outstanding new book This Thing of Darkness: Eisenstein's Ivan the Terrible in Stalin's Russia reflect the practice of this particular sub-genre of historical study. During our roundtable at the Association for Slavic, East European, and Eurasian Studies in November 2019, differences in disciplinary approaches to studying the creation of a work of art like Sergei Eisenstein's Ivan the Terrible shaped one key strand of the discussion. Below I focus on Neuberger's cultural-historical practice of the history of mentalités and study of reception, her approach to Eisenstein's artistic intentions and to his subjectivity, and her argument that Ivan the Terrible is a subversive work of art.

Historians tend to use works of art and literature to understand the societies that produced them, viewing them as "primary sources" that allow access to the worldviews or mentalités of their creators ${ }^{1}$. Neuberger's book is a tour-deforce that uses Eisenstein's filmic output, his theoretical and other critical writings, his personal notebooks and diaries, archival sources from the arts bureaucracies and memoirs of Eisenstein's associates to illuminate the worldview of both Eisenstein and of the Stalinist arts bureaucracy in the early 1940s. Neuberger shows "the potholed path" to making the film Ivan the Terrible during wartime evacuation in Alma Ata 


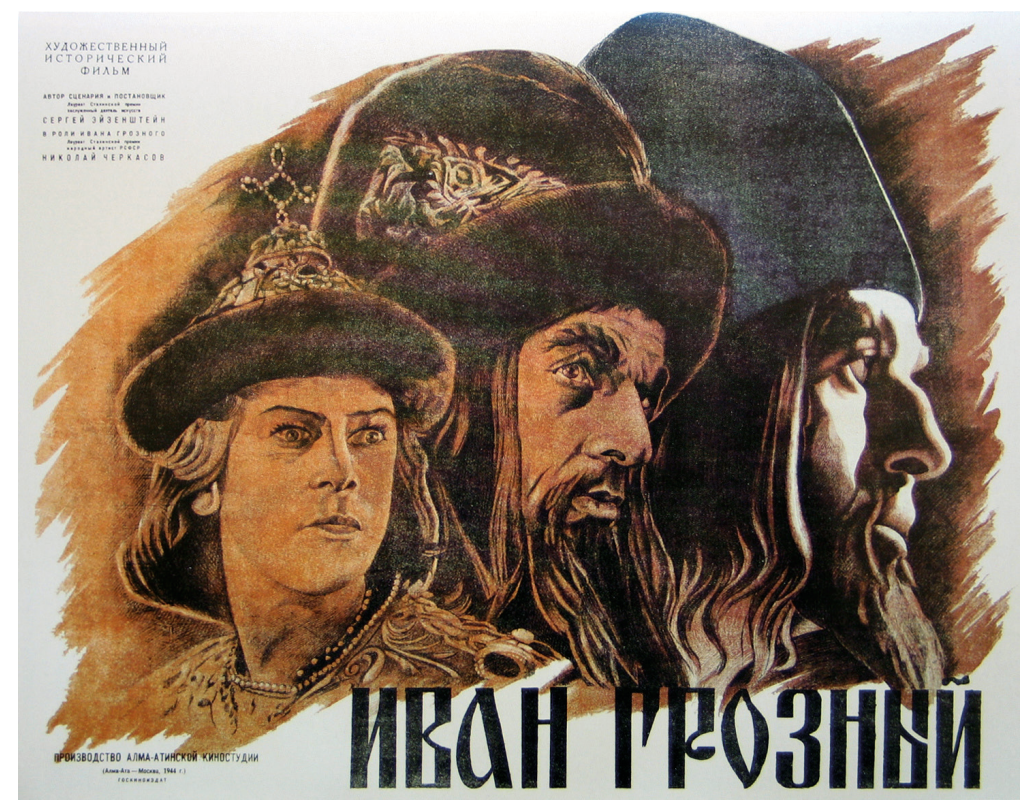

Film Poster for Ivan the Terrible, Part I (M. O. Dlugach, 1945). Published in: Afishi "Mosfil'ma", ed. by A.F.Shkliaruk (Moscow: Kontakt-kul'tura, 2012), p. 49.

(Almaty) as Eisenstein "negotiated the limits marked by the concepts and institutions of the Socialist Realist system, the hierarchy of committees, the material realities, and the knowledge of Stalin's ultimate gaze" (31).

Neuberger also ably explores the mindset of Stalinist authorities through documenting and examining the alterations that Eisenstein was forced to make in Part I during production to allow the film to be released, and through the authorities' reception of both parts of the films. In the case of Part I, which was publicly released in 1944, Neuberger also discusses the thoughts of a small group of Soviet filmgoers whose letters to Eisenstein were preserved in the archives. Neither arts authorities nor ordinary citizens knew quite what to make of Ivan the Terrible Part I, though Stalin (presumably) ultimately weighed in to overturn the negative recommendations of the prize committee and award the Stalin Prize to the film. The citizen letter-writers were also bewildered by the film's "murky" narrative structure and complained that "the film is tiresome instead of exciting" (313).

Neuberger shows that this ambivalent or confused reaction to Part I was much more positive than the outrage and horror of Soviet film directors and arts bureaucrats upon viewing Part II in early 1946, with its much more overt symbolism of Ivan as Stalin, Maliuta as Beria and the oprichniki as the NKVD. Part II portrays Ivan as a cold-blooded and violent leader, and Part II does not justify Ivan's actions as being for the good of the state. Following David Brandenberger and Kevin Platt, Neuberger's close readings of Stalin's comments on the film suggest that unlike the arts 
community, Stalin was not upset about Ivan's violence, but rather by the fact that Ivan was weak and Hamlet-like and not decisive or "terrible" enough². Neuberger's close reading of the sources surrounding Stalin's reactions also adds another possible layer to Stalin's outright disgust with the film: that Stalin was reacting negatively to Eisenstein's homoeroticism when he categorized both Ivan and the oprichniki as "degenerates" (328-329). These aspects of Neuberger's book reveal Eisenstein's process of creation in its very particular Stalinist context and demonstrate through a penetrating micro-history the complexities of being an artist in times of war and political persecution. Whatever were Eisenstein's intentions, he ultimately failed to deliver a decipherable (in the case of Part I) or acceptable (in the case of Part II) message about Ivan the Terrible to the Soviet public.

Neuberger's work leads directly to the question of Eisenstein's intentions and his subjectivity in the difficult circumstances of elite life under Stalinism ${ }^{3}$. Why did Eisenstein make artistic choices in both parts of Ivan the Terrible that were so far beyond what was generally acceptable in Stalinist culture? Neuberger demonstrates persuasively that many of Eisenstein's daring choices were censored from Part I. Both the homoeroticism and the persistent religiosity (including both Russian Orthodox and occult images) of Part II were themes that were not likely to pass the Soviet censors. Key to Neuberger's entire analysis is Sergei Eisenstein's agency as a writer, theorist and film-maker. Neuberger's attention to Eisenstein's mentality, his milieu, his work style, the technical aspects of his film-making, his theoretical interventions on film, and the other works he was reading and writing at the same time as Ivan provides a significant body of evidence from which she persuasively (to the mind of this cultural historian) constructs an argument about Eisenstein's mindset and intentions. Neuberger characterized Eisenstein's intervention into Soviet culture and politics through the film as "radical, critical and subversive" (344). Neuberger demonstrates that Eisenstein did not only pursue radical filmic techniques in his filmmaking, but also used the film to call into question the underpinnings of Stalinist politics. She argues that the historical themes that Eisenstein explored in the film, and especially Ivan's emotional vulnerability that leads to more and more violent actions, "contribute to a work of art that uncovers and dissects the monstrous principles and practices of Stalinist socialism" (344).

The question of whether Eisenstein's officially-recognized Stalinist art is subversive raises important questions that have been central to the scholarly literature about Soviet art. Cold War-era histories have tended to categorize Soviet artists into two neat categories of collaboration and resistance ${ }^{4}$. Neuberger's reading of Eisenstein is particularly relevant given these long-standing debates about the role of the artist in Stalinist culture, and the question of whether or to what extent it was possible to resist Soviet dictates during the extremely dangerous era from Stalin's purges to his death. Neuberger follows the post-Soviet scholarship that seeks to undercut this rigid binary of collaboration/resistance, avoiding the discordant debates of the 1970s and 1980s most famously encapsulated in "The Shostakovich Wars", in which scholars set up two mutually-exclusive and vituperative camps viewing the composer Dmitrii Shostakovich as either Stalin's toady or as a hero resisting Soviet dictates ${ }^{5}$. 
Neuberger has shown that a film like Ivan the Terrible that seems to be following the orders and dictates from above can be wildly subversive. Ivan the Terrible Part I was both commissioned by Stalin and won the Stalin Prize, yet Neuberger convincingly argues that it contains a profound and sustained critique of Stalinism. Whether the film could ever have successfully conveyed this critique to the vast majority of its viewers is another question, as Eisenstein's theoretically-sophisticated attempts to evoke the emotions of viewers and his deliberately complex narrative structures defying chronological time may have disquieted viewers without necessarily conveying the depths of the subversive message. It seems unlikely that the film could have succeeded in the rather utopian goal he expressed in his theoretical work Nonindifferent Nature, to convey to viewers the "thoughts, the feelings, the very being and existence of the author" (242).

Some literary scholars might critique Neuberger for the way that she ascribed intentionality to Eisenstein's work on the film Ivan the Terrible. While cultural historians like Neuberger tend to accept the literary-critical idea that a work of art like the film Ivan the Terrible is open to endless interpretations from its viewers, they do not tend to accept the "death of the author" or the notion that the intentions of the creator of the work are irrelevant to its interpretation ${ }^{6}$. Neuberger shows through prodigious research that Eisenstein made his theoretical writings manifest in his filmic output and that he worked toward a complex vision of Ivan that he simultaneously hoped would gain critical acclaim and question the underpinnings of Stalin's political power. This complexity and ambiguity that Neuberger finds within Eisenstein's own thought illuminates the question of subjectivity during Stalinism, both in terms of how Eisenstein portrays Ivan and in how Neuberger characterizes Eisenstein. Eisenstein's tragic Ivan seeks to achieve "unity" but remains a fractured subject, torn between "ambition, public commitment, and long-term historical or political goals, on the one hand, and personal human connection and moral responsibility, on the other" (184).

Eisenstein's own actions show a similar lack of "unity" as he simultaneously pursues an ambitious film project through the patronage of the elite Soviet arts bureaucracy including Stalin, convinced that because of his status and prestige he can evade rules and maintain artistic control, and at the same time producing a work that Neuberger argues "challenges every fundamental principle of Soviet socialist ideology and artistic practice: historical progress, the positive hero, dialectical materialism, revolutionary change, class consciousness, the cult of personality, hetero-normative sexuality, and model Soviet subjectivity" (344). Eisenstein shows that it is possible for one person to simultaneously assimilate to the rules and expectations of Stalinist society and at the same time deliver an overarching critique of the Soviet world view, providing strong evidence for the notion that top Soviet thinkers could ambivalently both praise and attack the system through Aesopian language and other covert means. For Eisenstein, all subjectivity is fractured, and subjects are always chasing the ideal of unity, while coping with all the disjointed contradictions in their personality. Thus Eisenstein critiques model Soviet subjectivity, but his work demonstrates that what might be perceived as a particularly "Soviet" phenomenon of fractured subjectivity is part of the universal condition. Eisenstein himself attacks 
the notion of unitary subjectivity and, by extension, viewing Soviet artists within a constrained framework of collaboration and resistance ${ }^{7}$.

This work is a tour de force that engages readers on many different levels from film theory and criticism to Stalinist politics and subjectivity. One aspect of the film's context, however, that might be explored even further is the effect of the cataclysm of the Second World War on the making of Ivan the Terrible. Neuberger addresses Eisenstein's grief at the loss of friends and the immense difficulties of creating a film after being evacuated, but I wonder whether the intense violence of the film reflects, in some way, Eisenstein's perceptions of the war. The strength of this book is that it operates on so many different levels of analysis, and while the war is not as fully fleshed out as it might be, this fact does not take away from Neuberger's mastery of Eisenstein's milieu.

1 Brooks J. When Russia Learned to Read: Literacy and Popular Literature, 1861-1917 (Evanston, 1985); Mally L. Revolutionary Acts: Amateur Theater and the Soviet State, 1917-1938 (Ithaca, 2000); Nelson A. Music for the Revolution: Musicians and Power in Early Soviet Russia (University Park, 2004); Petrone K. The Great War in Russian Memory (Bloomington, 2011); Stites R. Revolutionary Dreams: Utopian Vision and Experimental Life in the Russian Revolution (New York, 1988); Youngblood D. Movies for the Masses: Popular Cinema and Soviet Society in the 1920s (Cambridge, 1992).

2 See: Epic Revisionism: Russian History and Literature as Stalinist Propaganda, eds Kevin M.F.Platt, David Brandenberger (Madison, 2006); Platt K., Brandenebrger D. "Terribly Romantic, Terribly Progressive, or Terribly Tragic”, Russian Review, vol. 58, no. 4, 1999, pp. 635-654.

3 For discussions of Soviet subjectivity under Stalin see: Kotkin S. Magnetic Mountain: Stalinism as a Civilization (Berkeley, 1995); Halfin I., Hellbeck J. "Rethinking the Stalinist Subject: Stephen Kotkin's 'Magnetic Mountain' and the State of Soviet Historical Studies”, Jahrbücher für Geschichte Osteuropas, Bd.44, Nr.3, 1996, S. 456-463; Fitzpatrick S. Everyday Stalinism: Ordinary Life in Extraordinary Times: Soviet Russia in the 1930s (New York, 1999); Naiman E. "On Soviet Subjects and the Scholars Who Make Them", Russian Review, vol.60, no. 3, 2001, pp. 307-315; Hellbeck J. Revolution on My Mind: Writing a Diary under Stalin (Cambridge, 2006); Chatterjee C., Petrone K. "Models of Selfhood and Subjectivity: The Soviet Case in Historical Perspective", Slavic Review, vol.67, no. 4, 2008, pp.967-986.

4 See: Conquest R. The Great Terror: A Reassessment (New York, 1990), especially chap. 10; Brown M. C. Art Under Stalin (New York, 1991).

5 Musical scholars broke into camps of "revisionists" and "anti-revisionists" after the publication of Solomon Volkov: Volkov S. Testimony: The Memoirs of Dmitri Shostakovich, as related to and ed. by Solomon Volkov, transl. by Antonina W. Bouis (New York, 1979), a controversial revisionist work that portrayed Shostakovich as a dissident. Anti-revisionists, including Richard Taruskin and Laurel Fay, doubted the authenticity of this memoir and rejected the idea that Shostakovich took an oppositional stance to Stalin and Soviet cultural authorities. See: Fay L.E. Shostakovich: A Life (New York, 2000). Other scholars such as Allen Ho, have affirmed the narrative in Testimo$n y$ - see: Ho A. B., Feofanov D. Shostakovich Reconsidered (London, 1998).

6 Roland Barthes's 1967 essay "The Death of the Author", set off controversies over authorial intent in the field of literary criticism. See: Barthes R. Image - Music - Text (New York, 1978). For a critical response see: Burke S. The Death and Return of the Author: Criticism and Subjectivity in Barthes, Foucault, and Derrida, $3^{\text {rd }}$ ed. (Edinburgh, 2008).

7 For scholarship that goes beyond this dichotomy see: Clark K. The Soviet Novel: History as Ritual (Bloomington, 2000); Reid S. E. "Socialist Realism in the Stalinist Terror: The Industry of Socialism Art Exhibition, 1935-1941", The Russian Review, vol.60, no. 2, 2001, pp.153-184; Kiaer C. "Was Socialist Realism Forced Labour? The Case of Aleksandr Deineka in the 1930s", Oxford Art Journal, vol.28, no. 3, 2005, pp.323-345. 


\title{
FOR CITATION
}

Petrone K. 'Eisenstein's Ivan the Terrible and the History of Mentalités', Modern History of Russia, vol. 11, no. 1, 2021, pp. 233-239. https://doi.org/10.21638/11701/spbu24.2021.117 UDC 94(47).084.8

\begin{abstract}
This essay explores Joan Neuberger's book This Thing of Darkness (Cornell University Press, 2019) as a work of cultural history. It praises Neuberger's use of cultural-historical practices such as the history of mentalités and the study of reception to illuminate Sergei Eisenstein's artistic process and his subjectivity during the creation of Ivan the Terrible. Neuberger's work also illuminates the mentalités of the Soviet arts establishment seeking to restrain Eisenstein and keep him in line with Soviet cultural norms. Neuberger convincingly argues that Ivan the Terrible is a subversive critique of Stalin and Stalinism and she demonstrates that Eisenstein was able to assimilate to Soviet society while simultaneously criticizing Soviet power. It remains doubtful, however, whether Soviet audiences understood Eisenstein's cinematically complex critique. One aspect of the film's context, however, that might be explored even further is the effect of the cataclysm of the Second World War on the making of Ivan the Terrible. Neuberger addresses Eisenstein's grief at the loss of friends and the immense difficulties of creating a film after being evacuated, but author wonders whether the intense violence of the film reflects, in some way, Eisenstein's perceptions of the war. The strength of this book is that it operates on so many different levels of analysis, and while the war is not as fully fleshed out as it might be, this fact does not take away from Neuberger's mastery of Eisenstein's milieu.
\end{abstract}

Keywords: Eisenstein, Ivan the Terrible, Stalin, reception, Mentalités.

Author: Petrone K. - Professor of History, University of Kentucky (Lexington, USA); petrone@uky.edu

University of Kentucky, Department of History, Lexington, KY 40508, USA

\section{References:}

Barthes R. Image - Music - Text (New York, 1978).

Brooks J. When Russia Learned to Read: Literacy and Popular Literature, 1861 -1917 (Evanston, 1985).

Brown M. C. Art Under Stalin (New York, 1991).

Burke S. The Death and Return of the Author: Criticism and Subjectivity in Barthes, Foucault, and Derrida, $3^{\text {rd }}$ ed. (Edinburgh, 2008).

Chatterjee C., Petrone K. 'Models of Selfhood and Subjectivity: The Soviet Case in Historical Perspective', Slavic Review, vol. 67, no. 4, 2008.

Clark K. The Soviet Novel: History as Ritual (Bloomington, 2000).

Conquest R. The Great Terror: A Reassessment (New York, 1990).

Epic Revisionism: Russian History and Literature as Stalinist Propaganda, eds Kevin M. F. Platt, David Brandenberger (Madison, 2006).

Fay L. E. Shostakovich: A Life (New York, 2000).

Fitzpatrick S. Everyday Stalinism: Ordinary Life in Extraordinary Times: Soviet Russia in the 1930s (New York, 1999).

Halfin I., Hellbeck J. 'Rethinking the Stalinist Subject: Stephen Kotkin's 'Magnetic Mountain' and the State of Soviet Historical Studies', Jahrbücher für Geschichte Osteuropas, Bd. 44, Nr. 3, 1996.

Hellbeck J. Revolution on My Mind: Writing a Diary under Stalin (Cambridge, 2006).

Ho A. B., Feofanov D. Shostakovich Reconsidered (London, 1998).

Kiaer C. 'Was Socialist Realism Forced Labour? The Case of Aleksandr Deineka in the 1930s', Oxford Art Journal, vol. 28, no. 3, 2005.

Kotkin S. Magnetic Mountain: Stalinism as a Civilization (Berkeley, 1995).

Mally L. Revolutionary Acts: Amateur Theater and the Soviet State, 1917-1938 (Ithaca, 2000).

Naiman E. 'On Soviet Subjects and the Scholars Who Make Them', Russian Review, vol. 60, no. 3, 2001.

Nelson A. Music for the Revolution: Musicians and Power in Early Soviet Russia (University Park, 2004).

Petrone K. The Great War in Russian Memory (Bloomington, 2011).

Platt K., Brandenebrger D. 'Terribly Romantic, Terribly Progressive, or Terribly Tragic', Russian Review, vol. 58, no. 4, 1999. 
Reid S.E. 'Socialist Realism in the Stalinist Terror: The Industry of Socialism Art Exhibition, 1935-41', The Russian Review, vol.60, no. 2, 2001.

Stites R. Revolutionary Dreams: Utopian Vision and Experimental Life in the Russian Revolution (New York, 1988).

Volkov S. Testimony: The Memoirs of Dmitri Shostakovich, as related to and ed. by Solomon Volkov, transl. by Antonina W. Bouis (New York, 1979).

Youngblood D. Movies for the Masses: Popular Cinema and Soviet Society in the 1920s (Cambridge, 1992).

Received: June 18, 2020

Accepted: October 27, 2020 